\title{
History of the international collaboration of the Central TB Research Institute of Russian Academy Medical Science
}

\author{
OV Demikhova* \\ (CTRI) Central TB Research Institute, Moscow \\ *Corresponding author: OV Demikhova, (CTRI) Central TB Research Institute, Moscow
}

\begin{tabular}{|c|c|}
\hline ARTICLE INFO & ABSTRACT \\
\hline Received: 蔧 September 07, 2020 & Citation: OV Demikhova. History of the international collaboration of the Central TB \\
\hline Published: 慧 September 21, 2020 & $\begin{array}{l}\text { Research Institute of Russian Academy Medical Science. Biomed J Sci \& Tech Res 30(4)- } \\
\text { 2020. BJSTR. MS.ID.004970. }\end{array}$ \\
\hline
\end{tabular}

\section{Commentary}

In 2021 we are going to celebrate the $100^{\text {th }}$ anniversary of the Central TB Research institute (CTRI) foundation. During all these years the institute had close links with the international movement aimed to fight TB, which provided the basis for designation it as a WHO Collaborating Centre for Tuberculosis in the Russian Federation.

International cooperation in health started in 1851 from the International Sanitary Conference, which was convened to develop international marine quarantine regulations against the spread of cholera and other dangerous infectious diseases in Europe. The International Union Against Tuberculosis became the first international organization, which regularly coordinated scientific research and fight against TB in different countries.

This international organization was founded in 1920 on the initiative of scientists and doctors representing 33 countries. The first director of CTRI, Professor V.A. Vorobiev, was a member and one of the initiators of foundation of the International Union Against Tuberculosis. Since 1903 V.A. Vorobiev participated in the commission of the Pirogov Society, which aim was to study and fight socially dangerous diseases; in 1907 Vorobiev became the head of the commission; from 1910 through 1918 he was the chairman of the Board of the All-Russian League Against Tuberculosis[1]. From 1921 through 1926 he organized and headed the first TB chair of the medical faculty at the 1st Moscow State University and, at the same time, he participated in foundation of the State Tuberculosis
Institute (later, CTRI) in 1921 and was its director till 1933. Thus, from the start of its work CTRI was involved in international cooperation and global fight against TB. As a national leading TB institution, CTRI has been in the frontline and coordinated performance of all TB institutions countrywide.

The Central TB Research Institute areas of work:

1. Conducting scientific research and issuing a scientific journal.

2. Treatment of patients (children and adults).

3. Consultation of patients, including via telemedical technologies.

4. Rehabilitation of patients with lung diseases since 2018.

5. Trials of new drugs and vaccines.

6. Acting as a National Centre of Excellence "Tuberculosis Supranational Reference Laboratory Network".

7. Acting as a certified Training Centre for Postgraduate Education with a telemedicine department (a licence issued by the Russian Ministry of Health).

8. Cooperation with Russian and foreign research centres and international organizations.

9. Acting as a WHO Collaborating Centre for Tuberculosis in the Russian Federation since 1998. 
CTRI has been involved in active international cooperation for more than 60 years[2].

The main international partners include:

a. the World Health Organization (WHO).

b. the International Union Against Tuberculosis and Lung Diseases (hereinafter, the Union).

c. the European Respiratory Society.

d. cooperation under intergovernmental agreements.

e. interinstitutional cooperation.

In 1950-60s the exchange of scientific information, publications, correspondence between scientists, participation in national or international conferences held by the Union, ERS or other organizations became common. The representatives of the All-Union Medical Society of Phthisiologists founded in our country were elected and became members of the Executive Board of the International Union Against Tuberculosis and Lung Diseases. Professor A.G. Khomenko, Director of CTRI, was the chairman of the All-Union Medical Society of Phthisiologists; in 1978-1985 he was a member of the Executive Board of the Union. In 1986-1992 Professor V.V. Erokhin was a member of the Board. The work of the Union was targeted to experience exchange, improvement of measures against TB, expansion of participation and contribution of Russia into fight against TB [3].

To achieve these goals, our phthisiologists actively participated in programmatic and scientific committees, the Union Council and the European Region of the International Union Against Tuberculosis and Lung Disease in 1974-1976. Several CTRI specialists worked in different committees of the Union. These were academics of the Russian Academy of Medical Sciences (RAMS) L.K. Bogush, N.L. Shmelev, A.G. Khomenko; V.V. Erokhin, Besides, the Union members were Prof. M.M. Averbakh, V.V. Puzik, M.I. Oifebakh; and others. Prof. L.A. Mitinskaya, a member of the Union, was awarded a medal in commemoration of the 100th anniversary of Calmette.

The membership in the Executive Board of the Union ceased after the Soviet Union collapse; but many CTRI specialists are still members of the Union. The Union holds annual world conferences, which provides a platform for communication. Participation of our specialists in these annual events is currently the main form of cooperation with the Union.Interinstitutional cooperation (IIC) was a novel type of cooperation, which started in 1960s. The legal basis for IIC was interdepartmental agreements between the Soviet Ministry of Health and Ministries of Health of other countries. After the Soviet Union collapse, IIC was supported by agreements on cooperation between CTRI and institutes or centres from other countries working in the particular area of knowledge.

The first IIC research was performed together with Koranyi
Institute (the Hungarian People's Republic) in 1961-1962. The research was performed within the programme: "Combined chemotherapy of pulmonary TB". In 1965 a two-year agreement on cooperation was concluded with the Tuberculosis Research Institute of the German Democratic Republic (Berlin-Buch).In late 1960s - early 1970s (the second stage) we had the first experience of multilateral cooperation between the USSR and the Hungarian People's Republic, the German Democratic Republic, the Democratic Republic of Poland, the People's Republic of Bulgaria, the Czechoslovak Socialist Republic in such topics like: effectiveness of TB treatment, immunological studies of TB, isoniazid metabolism, classification of acid-fast bacilli. In 1986-1995 CTRI conducted joint research studies with the institutes of socialist countries like Hungary, Germany, Bulgaria, Czechoslovakia, Romania, Yugoslavia, China, and with TB-related institutions of the United Kingdom, the Federal Republic of Germany (a hospital of lung diseases in Heidelberg; a university hospital in Mainz), the Centre for the study of host resistance in Montreal (Canada), Saint Louis lung clinic in Paris (France).

Besides joint international projects related to TB, our institute also conducted studies of sarcoidosis and hypersensitivity pneumonitis. In association with the Yugoslavian Clinic of Non-Specific Lung Diseases, we conducted a research study entitled: "Etiology, genetics, immunodiagnostics of sarcoidosis and exogenic allergic alveolitis". Its aim was to develop programmes of antioxidant therapy, to study etiology, genetics and immunodiagnostics of sarcoidosis and exogenic allergic alveolitis. Together with German scientists we published a monograph entitled: "Exogenous allergic alveolitis", edited by Khomenko A.G., Myuller S., Shilling V. (1987). By the end of 1990 our institute accomplished 18 thematic researches in cooperation with other institutes from: the Hungarian People's Republic (3), the German Democratic Republic (2), the Democratic Republic of Poland (2), the People's Republic of Bulgaria (4), the Czechoslovak Socialist Republic (3), the Socialist Republic of Romania (3), and the Socialist Federative Republic of Yugoslavia (1).

According to the agreement on interinstitutional cooperation between the Microbiology reference laboratory at the Royal College in London (the UK) and the Molecular genetics laboratory at CTRI, we conducted a joint research: "Drug resistance in the Russian Federation", which involved genotyping of M. tuberculosis strains isolated from TB patients in Samara region. The research was done under the cooperative project of the Department of Health and Social Care (the UK) and the Ministry of Health (Russia). In 2000-2007 the Hekeshorn pulmonology clinic in Berlin conducted a postgraduate education course, which was attended by 3-4 specialists from CTRI every year.

In the framework of interinstitutional cooperation, we conducted a joint research together with the Max Planck Institute for Infection Biology (Berlin) entitled: "The immune response to Mycobacterium 
tuberculosis infection in humans"; the immunomorphology of lung granulomas in humans was studied.To investigate spread and detection of multidrug-resistant (MDR) TB in different countries of the CIS, since 2011 we have conducted a joint study with the Research Institute of Pulmonology and Tuberculosis (Belarus) and the Republican specialized scientific research medical centre of phthisiology and pulmonology (Uzbekistan): "The spread of multidrug-resistant strains of $\mathrm{M}$. tuberculosis and ways to improve effectiveness of MDR TB treatment"; an interinstitutional research by CTRI and the National Research Institute of Tuberculosis (Azerbaijan): "The spread of primary and acquired multidrug resistance of $\mathrm{M}$. tuberculosis strains in different countries of the CIS". In 2013 we concluded an agreement with the University of Texas on cooperation in the areas of mutual interest.

In 2016 we concluded bilateral agreements on joint studies with Pasteur Institute of Iran and the Republican specialized scientific research medical centre of phthisiology and pulmonology (Uzbekistan). We prepared a new draft agreement with the Republican Scientific and Practical Center of Pulmonology and Tuberculosis (Belarus). In 2017 we concluded a memorandum on cooperation with the University of Havana (Cuba).Cooperation under intergovernmental agreements began from 1969. In January 1969 the USSR and France concluded an intergovernmental agreement on cooperation in health and medical science.In 1976 the research plan included 3 topics on "non-specific lung diseases": "Early diagnosis of lung diseases", "Biochemistry, immunology and bacteriology of chronic bronchitis", "Pulmonary surfactant in health and human lung diseases".

The both parties agreed that the most effective study of the surfactant system was performed using electron microscopy. The responsible person from CTRI was Prof. V.V. Erokhin, who headed the department of pathomorphology and the laboratory of electron microscopy in that period. We published joint articles in France and the USSR. The cooperation took place in 1980s.Cooperation in the framework of intergovernmental agreements continued in the late 1990s and has been underway since 2000 till now. In the framework of the agreement between the United States and the Russian Federation, according to the agreement on cooperation between CTRI, Orel and Vladimir regions, the Centers for disease control and prevention (CDC), and under support of the PETTS (Preserving Effective TB Treatment Study) grant, joint researches were carried out in nine countries (Russia, Estonia, Latvia,Peru, South Korea, Taiwan, the Philippines, South Africa, Thailand) to study multidrug-resistant $M$. tuberculosis strains and how to preserve effectiveness of TB treatment with second-line drugs. Several articles were published. The analyses and publications related to PETTS are still underway.

Under the intergovernmental agreement between the Ministry of Health and Social Development (Russia) and the American
International Health Alliance in association with the United States Agency for International Development, CTRI implemented the programme: "Strategic partnership in health care". In the framework of the programme two training modules were issued in 2012: "Laboratory diagnosis of TB" and "Diagnosis and management of multidrug-resistant TB". Since 2008 a five-year project of the EU 7th Framework Programme on coordination and support of response to TB and HIV-infection had been implemented.Besides the European countries, the project involved Russia (CTRI and Ivanovsky Institute of Virology), India, the South African and Latin American countries. It resulted in the development of a roadmap to combat TB and HIV-infection. Several articles were published.

In 2008 an agreement between the Ministry of Health and Social Development (Russia) and the Federal Ministry of Health (Germany) was concluded. It was about cooperation between CTRI and Koch-Mechnikov Forum established in 2006 under the intergovernmental agreement between Russia and Germany, which was still in force. On 11-13 May 2016, CTRI in association with the Russian Science Foundation (grant 15-15-30020, KТК) held a joint conference of CTRI and Koch-Mechnikov Forum: "Inflammation in the lung tissue: pathogenesis, regulation, immune response" and an international Young Scientists School. The young scientists could listen to the lectures of Russian and foreign renowned clinicians and scientists: Prof. David McMurray (the University of Texas), the corresponding member of the RAMS Prof. S.A. Nedospasov (the Moscow State University), Prof. A.S. Apt (CTRI), Prof. Olivier Neyrolles (the Institute of Pharmacology and Structural Biology, University of Toulouse), Prof. Igor Kramnik (the Boston University), Prof. Anca Dorhoi (Max Plank Institute, Berlin), Prof. E. Eruslanova (the University of Pennsylvania).

Since the foundation of the World Health Organization (WHO), which is one of the specialized agencies of the United Nations Organization (UNO) related to health care, international cooperation in TB control has been implemented under the patronage of the WHO and the Union. The WHO Collaborating Centre for Tuberculosis at the Central TB Research Institute (CTRI) celebrated its 20th anniversary in 2018. The WHO designates a collaborating centre for a four-year period, which can be followed by redesignation[3]. In January 2019 the WHO redesignated CTRI as a Collaborating Centre for another four-year period.At the present time, as precede 100 years, CTRI is opened for collaboration and new projects.

\section{References}

1. Nikolsky AV (1911) Tuberculosis in Russia and the fight against it. Tuberculosis. J All-Russian League for Tuberculosis Control 1: 1-11.

2. Khomenko AG (1971) Theory and practice of TB control as a public health issue. Moscow, Medicine pp. 151

3. (2017) World Health Organization (WHO) 2017. Guide for WHO collaborating centers. Geneva, WHO p. 55. 
ISSN: 2574-1241

DOI: 10.26717/BJSTR.2020.30.004970

oV Demikhova. Biomed J Sci \& Tech Res

(c) (P) This work is licensed under Creative

Submission Link: https://biomedres.us/submit-manuscript.php

$\begin{array}{ll}\text { BIOMEDICAL } & \text { Assets of Publishing with us } \\ \text { RESEARCHES } & \text { Global archiving of articles } \\ & \text { - Immediate, unrestricted online access } \\ & \text { - Rigorous Peer Review Process } \\ & \text { - Anthors Retain Copyrights }\end{array}$

